\title{
Optimizing the impact of temperature on bio-hydrogen production from food waste and its derivatives under no $\mathrm{pH}$ control using statistical modelling
}

\author{
C. Arslan ${ }^{1,2, *}$, A. Sattar ${ }^{1, *}$, C. Ji ${ }^{1}$, S. Sattar ${ }^{3}$, K. Yousaf ${ }^{1}$, and S. Hashim ${ }^{4}$ \\ ${ }^{1}$ College of Engineering, Nanjing Agricultural University, Nanjing, China \\ ${ }^{2}$ Department of Structures and Environmental Engineering, University of Agriculture, Faisalabad, Pakistan \\ ${ }^{3}$ Environmental Sciences and Engineering, GC University Faisalabad, Pakistan \\ ${ }^{4}$ Department of Hydrology and Water Resources, Hohai University, Nanjing, China \\ *These authors contributed equally to this work.
}

Correspondence to: C. Ji (chyji@njau.edu.cn, arslanakrampk@hotmail.com)

Received: 6 July 2015 - Published in Biogeosciences Discuss.: 11 August 2015

Revised: 12 October 2015 - Accepted: 27 October 2015 - Published: 13 November 2015

\begin{abstract}
The effect of temperature on bio-hydrogen production by co-digestion of sewerage sludge with food waste and its two derivatives, i.e. noodle waste and rice waste, was investigated by statistical modelling. Experimental results showed that increasing temperature from mesophilic $\left(37^{\circ} \mathrm{C}\right)$ to thermophilic $\left(55^{\circ} \mathrm{C}\right)$ was an effective mean for increasing bio-hydrogen production from food waste and noodle waste, but it caused a negative impact on bio-hydrogen production from rice waste. The maximum cumulative biohydrogen production of $650 \mathrm{~mL}$ was obtained from noodle waste under thermophilic temperature condition. Most of the production was observed during the first $48 \mathrm{~h}$ of incubation, which continued until $72 \mathrm{~h}$ of incubation. The decline in $\mathrm{pH}$ during this interval was 4.3 and 4.4 from a starting value of 7 under mesophilic and thermophilic conditions, respectively. Most of the glucose consumption was also observed during $72 \mathrm{~h}$ of incubation and the maximum consumption was observed during the first $24 \mathrm{~h}$, which was the same duration where the maximum $\mathrm{pH}$ drop occurred. The maximum hydrogen yields of $82.47 \mathrm{~mL} \mathrm{VS}^{-1}, 131.38 \mathrm{~mL} \mathrm{COD}^{-1}$, and $44.90 \mathrm{~mL}_{\text {glucose }}{ }^{-1}$ were obtained from thermophilic food waste, thermophilic noodle waste and mesophilic rice waste, respectively. The production of volatile fatty acids increased with an increase in time and temperature in food waste and noodle waste reactors whereas they decreased with temperature in rice waste reactors. The statistical modelling returned good results with high values of coefficient of determination
\end{abstract}

$\left(R^{2}\right)$ for each waste type and 3-D response surface plots developed by using models developed. These plots developed a better understanding regarding the impact of temperature and incubation time on bio-hydrogen production trend, glucose consumption during incubation and volatile fatty acids production.

\section{Introduction}

Anaerobic digestion, as a waste management approach, has been in practice for more than a century (McCarty, 1981). It is widely used to treat a variety of solid wastes and wastewater on a small scale as well as on an industrial scale. It has multiple advantages like $30-50 \%$ reduction in waste volume as well as production of valuable byproducts such as methane and hydrogen (Lin et al., 2011). A large amount of organic fraction of municipal solid waste or food waste is produced every year around the world. During 2010, production of food waste in China reached $352 \mathrm{Mt}$ and the major contributor was canteens and restaurants (Tai et al., 2011; Wang et al., 2013). The food waste contains more than $80 \%$ volatile solids (VS) that are biodegradable solids and can be converted into hydrogen or methane easily (Shin et al., 2004; Zhang et al., 2007; Zhu et al., 2008). Several studies represent an increase in bio-hydrogen production from food waste due to the addition of buffers and minerals. Although such 
addition can maintain a specific $\mathrm{pH}$ and nutrimental required for optimum bio-hydrogen production, but it also increases the cost of production (Nielsen et al., 2001; Han, 2004). The cost of production can be reduced by adding sewage sludge as a source of Clostridium mix culture (Fang et al., 2006). Nutritional deficiency in food waste was also balanced by adding sewage sludge that made food waste more suitable for bio-hydrogen production (Shin et al., 2004). It means that integrated waste management can be done at a wastewater treatment plant by co-digestion of sewage sludge and food waste. Although sewerage sludge is a good source of Clostridium mix culture, it also contains hydrogen consumers like methanogens. Heat treatment is mostly opted to deactivate hydrogen consumers. The traditional method of placing sewage sludge in boiling water is now no longer in practice and is replaced by microwave heating that provide more uniform heating as compared to the boiling water method (Luo et al., 2010; Wang et al., 2011; Duangmanee et al., 2007). The temperature and time for heat treatment varied from 75 to $121^{\circ} \mathrm{C}$ for $15 \mathrm{~min}$ to $2 \mathrm{~h}$, but $100^{\circ} \mathrm{C}$ for $15 \mathrm{~min}$ was mostly reported (Li and Fang, 2007; Fang et al., 2006).

Carbohydrate-rich wastes like food waste are suitable for Clostridium species as stoichiometrically it can produce two moles of hydrogen from one mole of hexose (Payot, 1998). Theoretically, $553 \mathrm{~mL}$ hydrogen can be produced by $1 \mathrm{~g}$ of polysaccharides if it is totally converted into acetate. The highest practical yield of $346 \mathrm{~mL} \mathrm{~g}^{-1}$ carbohydrate was achieved by Fang et al. (2006) by using rice as a source of carbohydrate (78\%), pre-treated sewage sludge as a source of Clostridium and adding a variety of nutrients. Rice waste and noodle waste has $40 \%$ share in the total food waste produced in China (Shiwei, 2005). The noodle waste is also rich in carbohydrates, but still there is no research reported on bio-hydrogen production from noodle waste.

Temperature and $\mathrm{pH}$ have a great impact on the smooth running of AD (Saraphirom and Reungsang, 2010). Most of the studies reported bio-hydrogen production under mesophilic as well as thermophilic conditions and few were reported under psychrophilic conditions. Lu et al. (2011) developed microbial electrolysis cells (MECs) that could be operated at $9{ }^{\circ} \mathrm{C}$ by using Geobacter psychrophilus as dominating population and achieved a hydrogen yield of $0.62 \mathrm{~m}^{3} \mathrm{H}_{2} \mathrm{~m}^{-3} \mathrm{~d}^{-1}$. Heidrich et al. (2013) further modified MECs to a pilot-scale MEC and achieved bio-hydrogen production of $0.015 \mathrm{LH}_{2} \mathrm{~L}^{-1} \mathrm{~d}^{-1}$ at $25^{\circ} \mathrm{C}$. On the other end, under mesophilic and thermophilic conditions, there is no need for such sophisticated technology and a better bio-hydrogen yield can be achieved by simple reactors or by lab scale batch experiments. The temperature shift from mesophilic to thermophilic conditions can change the rate of hydrogen production during anaerobic digestion ( $\mathrm{Li}$ and Liu, 2012; Saripan and Reungsang, 2014). Whereas hyper-thermophilic provide better pathogenic destruction but it also decreased the bio-hydrogen production (Sahlström, 2003; Yokoyama et al., 2007). Keeping the same temperature but changing the initial
$\mathrm{pH}$ from 7 to 8 , the bio-hydrogen yield was changed from 64.48 to $55 \mathrm{~mL} \mathrm{VS}^{-1}$ under no $\mathrm{pH}$ control conditions (Lin et al., 2013b; Nathao et al., 2013). The same yield was increased to $70 \mathrm{~mL} \mathrm{VS}^{-1}$ when $\mathrm{pH}$ was manually controlled for food waste under thermophilic conditions, which represents the impact of $\mathrm{pH}$ management (Shin et al., 2004). The hydrogen production by anaerobic digestion will be further improved if $\mathrm{pH}$ lies in the range of 5 to 6 (Radjaram and Saravanane, 2011). The $\mathrm{pH}$ of food waste lies in the range of 4 to 5 , which further decreases by the production of volatile fatty acids (VFA) to such a level that can inhibit the bacterial growth. The $\mathrm{pH}$ can be controlled by automatic $\mathrm{pH}$ controllers, addition of nutrients and buffers, manual monitoring and control (Yasin et al., 2011; Zhu et al., 2008; Kim et al., 2004). But all these methods increased the cost of operation. Along with cost, maintaining $\mathrm{pH}$ at specific point is not suitable especially when mix culture is used as the response of different microbial stream could be different to same $\mathrm{pH}$ level. So, by co-digestion, the $\mathrm{pH}$ of the anaerobic digestion process can be improved and it can be further adjusted to a desired initial value by adding $\mathrm{HCl}$ or $\mathrm{NaOH}$. After adjusting the desired initial $\mathrm{pH}$ under co-digested conditions, the biohydrogen production can be achieved under no $\mathrm{pH}$ control conditions, which can reduce the cost of operation (Fang et al., 2006).

The yield of bio-hydrogen is calculated by dividing the cumulative hydrogen produced by VS, chemical oxygen demand (COD) or glucose (Chen et al., 2006; Dong et al., 2009; Fang et al., 2006). The yields are misleading if calculated in terms of added or start up values of VS, COD and glucose as it seems quite impossible that the whole of added material is converted into hydrogen. In this regard the removal quantities of such parameters are the best option to calculate the yield.

The optimization played an important role in bio-hydrogen production and its application with respect to incubation time in combination with temperature is an important factor to get the maximum output with minimum intake of energy. In order to achieve this purpose, statistical modelling is an important tool to study the impact within the experimental range and can be further used for the development of response surface plots (Jo et al., 2008).

This study was designed to investigate the impact of temperature on bio-hydrogen production from co-digestion of sewerage sludge with food waste and its carbohydrate-rich derivatives i.e. rice waste and noodle waste with the help of statistical modelling. The response surface methodology was employed to study the impact of time and temperature on bio-hydrogen production, glucose consumption and VFA production. The $\mathrm{pH}$ during incubation was not controlled and the drop of $\mathrm{pH}$ during anaerobic digestion was also studied to find an optimum $\mathrm{pH}$ range of bio-hydrogen production from food waste derivatives. 


\section{Material and methods}

\subsection{Batch experiment for bio-hydrogen production}

The waste was collected from student dining at the Nanjing Agricultural University. The food left on the plates after lunch/dinner consisted of rice, noodles, meat, bones, potato and other vegetables. At first, bones and other foreign materials were removed and left over waste was treated as food waste. The food waste was then ground in a meat grinder with an equal amount of water and a resultant slurry was used for bio-hydrogen production (Reungsang et al., 2013). Rice and noodles were removed from collected waste and converted into slurry in the same way opted for food waste. The sludge was obtained from a settling channel and it was washed with tap water and sieved to remove foreign materials (Nathao et al., 2013). The sludge was placed in a preheated oven at $100^{\circ} \mathrm{C}$ for $15 \mathrm{~min}$, so that hydrogenotrophic methanogens could be deactivated ( $\mathrm{Li}$ and Fang, 2007). Some important properties of feed stock and sewerage sludge are enlisted in Table 1.

Two series of experiments were conducted in duplicate in $550 \mathrm{~mL}$ digesters with working volume of $400 \mathrm{~mL}$ (Hu et al., 2014). In order to achieve $10 \%$ initial TS concentration, water was added along with feedstock and sewerage sludge in the digesters. The feedstock and sewerage sludge were added in equal proportion. As the $\mathrm{pH}$ of food waste was not so high even after co-digestion with sewage sludge, the initial $\mathrm{pH}$ within reactor was less than 7 which was carefully raised to 7 with the help of $3 \mathrm{M} \mathrm{NaOH}$ solution (Zhu et al., 2008). Series I was to observe the bio-hydrogen production under mesophilic temperature $\left(37^{\circ} \mathrm{C}\right)$ and series II was to investigate the impact of thermophilic temperature $\left(55^{\circ} \mathrm{C}\right)$ on biohydrogen production potential of feed stock in comparison with that produced under mesophilic conditions.

\subsection{Chemical analysis}

The volume of bio-hydrogen produced was measured by displacement of $3 \% \mathrm{NaOH}$ solution. This concentration of $\mathrm{NaOH}$ can remove other gases and water vapours (Fang et al., 2006; Lin et al., 2013a; Saraphirom and Reungsang, 2010). Other parameters like TS, VS, COD, VFA and alkalinity were measured according to standard methods (APHA, 2005). For glucose detection, phenol sulphuric acid method was used (Lay and Fan, 2003).

\subsection{Assay methods}

Modelling of hydrogen production was done by Modified Gompertz equation (MGE), which was used for cumulative bio-hydrogen measurement (Ramos et al., 2012)

$H=\operatorname{Pexp}\left\{-\exp \left[\frac{R_{\mathrm{m}} e}{P}(\lambda-t)+1\right]\right\}$ where $H, t, P, R_{\mathrm{m}}, \lambda$ and $e$ represent cumulative bio-hydrogen production $(\mathrm{mL})$, incubation time $(\mathrm{h})$, biohydrogen production potential, maximum bio-hydrogen production rate $\left(\mathrm{mLh}^{-1}\right)$, lag phase duration (h) and 2.71828 respectively. The values of $H, t, P, R_{\mathrm{m}}$ were solved by using curve fitting tool in (ver. 2010a).

In this study, the effects of different types of food waste, temperature and incubation time on bio-hydrogen and VFA production as well as on glucose consumption, were analysed by full quadratic model as shown below (Kim et al., 2008; Jo et al., 2008)

$Y=a_{0}+\sum_{i=1}^{n} a_{i} X_{i}+\sum_{i=1}^{n} a_{i i} X_{i}^{2}$
$+\sum_{i=1}^{n} \sum_{i<j=2}^{n} a_{i j} X_{i} X_{j}$,

where $X_{i}$ and $X_{j}$ are the controlled parameters, which influence $Y$ and $a_{0}, a_{i i}, a_{i j}$, are the offset term, linear and quadratic coefficients respectively. As the waste types are different, so the above model is used, including waste type $(n=3)$ and excluding waste type $(n=2)$.

\section{Results and discussion}

\subsection{Effect of temperature and time on bio-hydrogen production}

A comparison of actual and MGE modelled bio-hydrogen production under mesophilic and thermophilic conditions is shown in Fig. 1, which shows an early start of bio-hydrogen production in food waste and noodle waste as compared to rice waste. This early production was quantified with the help of MGE as $\lambda$ shown in Table 2, which clearly shows that the highest lag phase belongs to rice waste under both temperatures. The bio-hydrogen production in food waste continued until $72 \mathrm{~h}$ of incubation and this time period for food waste was higher than that observed for noodle waste, but still the cumulative bio-hydrogen production of food waste was the lowest as compared to the other two waste types. Looking at the $R_{\mathrm{m}}$ values, it is clear that food waste has the lowest mesophilic $R_{\mathrm{m}}$ value of $6.688 \mathrm{~mL} \mathrm{~h}^{-1}$ among all three wastes that ultimately caused the cumulative bio-hydrogen production to decrease. Only the $R_{\mathrm{m}}$ value is not responsible for higher yield as the highest mesophilic $R_{\mathrm{m}}$ of $21.05 \mathrm{~mL} \mathrm{~h}^{-1}$ belongs to noodle waste, but the cumulative bio-hydrogen production of noodle waste was found to be smaller than rice waste having $R_{\mathrm{m}}$ value of $16.52 \mathrm{~mL} \mathrm{~h}^{-1}$. The rice waste has a higher production because it produced bio-hydrogen for $96 \mathrm{~h}$ as compared to noodle waste which produced until $60 \mathrm{~h}$. In fact, mesophilic bio-hydrogen production in noodle waste decreased considerably after $24 \mathrm{~h}$ of incubation as compared to thermophilic bio-hydrogen production where the decrease was observed after $36 \mathrm{~h}$ of incubation. That is $12 \mathrm{~h}$ active duration increased the cumulative bio-hydrogen production from noodle waste under thermophilic temperature even after observing the fact that the $R_{\mathrm{m}}$ values are very 
Table 1. Properties of test materials.

\begin{tabular}{llrrrr}
\hline Parameter & Unit & Sludge & Food waste & Rice waste & Noodles waste \\
\hline TS & $\%$ & 58.59 & 30.32 & 39.88 & 31.54 \\
VS & $\%$ & 2.87 & 26.9 & 39.30 & 28.51 \\
Glucose & $\mathrm{g} \mathrm{L}^{-1}$ & 2.49 & 65.77 & 79.65 & 63.73 \\
COD & $\mathrm{g} \mathrm{L}^{-1}$ & 50 & 147.5 & 105 & 132 \\
Total Alkalinity & $\mathrm{mg} \mathrm{L}^{-1}$ & 3700 & 550 & 500 & 450 \\
VFA (mg L & -1 \\
pH & $\mathrm{mg} \mathrm{L}^{-1}$ & 13950 & 2475 & 9000 & 1500 \\
& - & 7.1 & 4.5 & 5.3 & 4.3 \\
\hline
\end{tabular}

close to each other. It can be seen in Fig. 2 that the difference in active duration was due to $\mathrm{pH}$ as it was dropped from 7 to 4.6 in the noodle waste reactor during the first $12 \mathrm{~h}$ under mesophilic temperature and it was further dropped to 4.4 whereas a pH drop in thermophilic reactor was 5.3 to 4.9 in the same duration. On the other end, $\mathrm{pH}$ drop in rice waste reactor under thermophilic conditions was higher as compared to mesophilic temperature, which ultimately reduced the cumulative bio-hydrogen production that was found in agreement with the finding of Fang et al. (2006). The reduction in bio-hydrogen production with low $\mathrm{pH}$ is due to homoacetogenic bacteria, which are more active at low $\mathrm{pH}$ (Ramos et al., 2012; Schiel-Bengelsdorf and Dürre, 2012). The trend for $\mathrm{pH}$ drop with temperature in food waste reactors was opposite to other reactors and $R_{\mathrm{m}}$ increased to a value of $26.42 \mathrm{~mL} \mathrm{~h}^{-1}$ when temperature was shifted from mesophilic to thermophilic. This increase is due to Thermoanaerobacterium thermosaccharolyticum that grow at higher temperature in food waste and produce more hydrogen (Shin et al., 2004 ). As a whole, $R_{\mathrm{m}}$ values found in the present study were higher than those reported in previous studies (Fang et al., 2006; Ramos et al., 2012).

The volume of bio-hydrogen production with time was used to fit in a quadratic model by using solver function MS Excel and the resultant equation obtained was

$$
\begin{aligned}
& Y=202.83+56.86 x_{1}+73.38 x_{2}+8.5 x_{3}-22.5 x_{1}^{2} \\
& +243.25 x_{2}^{2}-113.8 x_{3}^{2}-23.75 x_{1} x_{2}-1.86 x_{1} x_{3} \\
& -30.38 a_{9} x_{2} x_{3}\left(R^{2}=0.5576, F=19.921\right),
\end{aligned}
$$

where $Y$ is the predicted bio-hydrogen production; $x_{1}, x_{2}$ and $x_{3}$ are the coded values of incubation time, waste type and temperature respectively. There is a poor relationship between actual and predicted value as the coefficient of determination $\left(R^{2}\right)$ was calculated to be 0.5576 , which can explain only $55.76 \%$ variability of the response. The diversity among waste type is the main reason for such a low value and this value could be at a higher level if the same waste was used in different proportions as reported in other studies (Kim et al., 2008; Jo et al., 2008). To overcome this problem, quadratic model was again developed for each waste type and the following equations were obtained:
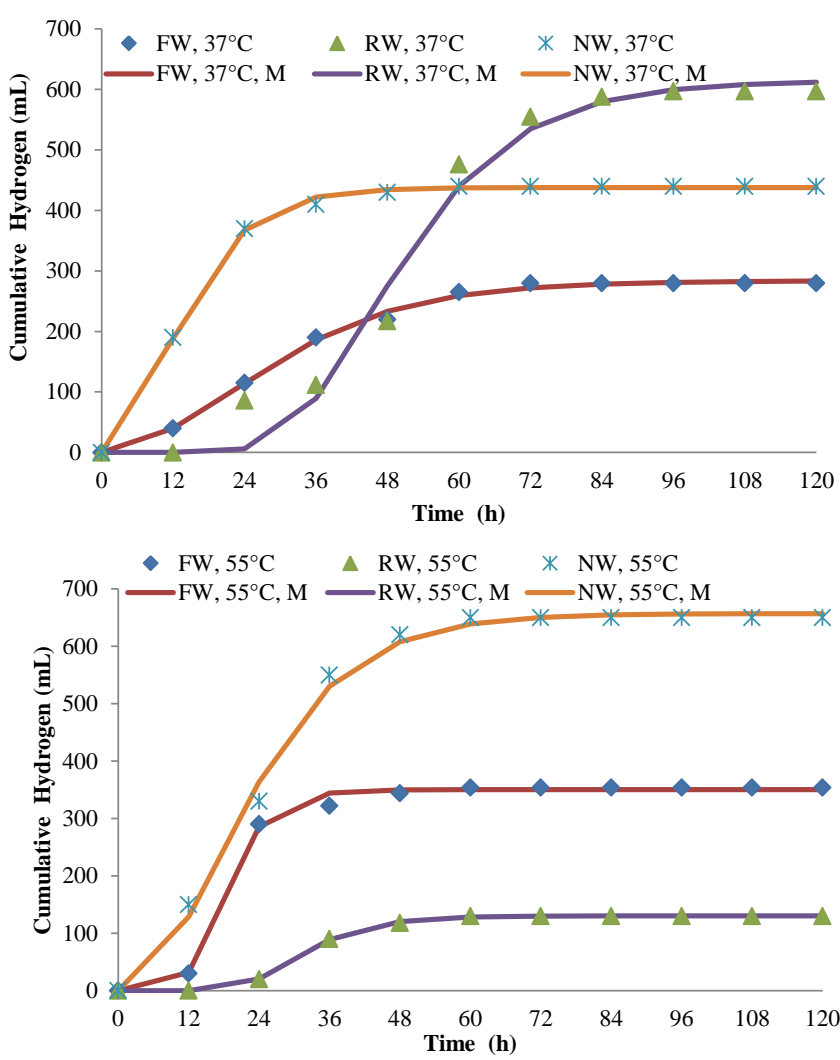

Figure 1. Mesophilic and thermophilic bio-hydrogen production with time.

Food waste: $Y=281.75+57.25 x_{1}+62.25 x_{2}$

$-22 x_{1}^{2}-25.25 x_{1} x_{2}\left(R^{2}=0.9858 F=278.06\right)$

Noodle waste: $Y=472.5+97.5 x_{1}+42.5 x_{2}$

$-25 x_{1}^{2}+62.5 x_{1} x_{2}\left(R^{2}=0.9011 F=36.44\right)$

Rice waste : $Y=167.5+71.5 x_{1}-49.5 x_{2}$

$-43 x_{1}^{2}-16.5 x_{1} x_{2}\left(R^{2}=0.7922 F=15.26\right)$,

where $x_{1}$ and $x_{2}$ are the coded values of time and temperature. All $F$ values represented that the regression model obtained are statistically significant. The $F$ value of food waste 
Table 2. Kinetic parameters and bio-hydrogen yield.

\begin{tabular}{|c|c|c|c|c|c|c|c|c|c|}
\hline \multirow[b]{2}{*}{$\begin{array}{l}\text { Waste } \\
\text { Type }\end{array}$} & \multirow[b]{2}{*}{ Temperature } & \multirow[b]{2}{*}{$\begin{array}{r}P \\
(\mathrm{~mL})\end{array}$} & \multirow[b]{2}{*}{$\begin{array}{r}R_{\mathrm{m}} \\
\left(\mathrm{mLh}^{-1}\right)\end{array}$} & \multirow[b]{2}{*}{$\begin{array}{r}\lambda \\
\text { (h) }\end{array}$} & \multirow[b]{2}{*}{$R^{2}$} & \multicolumn{4}{|c|}{ Hydrogen yield } \\
\hline & & & & & & $\begin{array}{r}\mathrm{mLg}^{-1} \mathrm{VS} \\
\text { Fed }\end{array}$ & $\begin{array}{r}\mathrm{mLg}^{-1} \mathrm{VS} \\
\text { Removed }\end{array}$ & $\begin{array}{r}\mathrm{mL} \mathrm{g}^{-1} \mathrm{COD} \\
\text { Removed }\end{array}$ & $\begin{array}{r}\mathrm{mL} \mathrm{g}^{-1} \text { glucose } \\
\text { Removed }\end{array}$ \\
\hline \multirow[t]{2}{*}{ FW } & $37^{\circ} \mathrm{C}$ & 283.7 & 6.688 & 6.949 & 0.9971 & 17.59 & 80.11 & 47.28 & 18.02 \\
\hline & $55^{\circ} \mathrm{C}$ & 350.1 & 26.42 & 11.39 & 0.9965 & 21.57 & 82.47 & 67.33 & 25.63 \\
\hline \multirow[t]{2}{*}{ RW } & $37^{\circ} \mathrm{C}$ & 614.3 & 16.52 & 31.29 & 0.9819 & 32.76 & 56.36 & 66.77 & 44.90 \\
\hline & $55^{\circ} \mathrm{C}$ & 130.2 & 6.325 & 21.1 & 0.9997 & 6.94 & 29.66 & 26.04 & 8.68 \\
\hline \multirow[t]{2}{*}{ NW } & $37^{\circ} \mathrm{C}$ & 437.9 & 21.05 & 3.047 & 0.9987 & 15.26 & 23.40 & 109.48 & 27.65 \\
\hline & $55^{\circ} \mathrm{C}$ & 656.9 & 20.41 & 5.935 & 0.9955 & 22.89 & 38.15 & 131.38 & 40.33 \\
\hline
\end{tabular}

Table 3. Comparison of bio-hydrogen yield.

\begin{tabular}{|c|c|c|c|c|c|c|c|}
\hline $\begin{array}{l}\text { Feed } \\
\text { stock }\end{array}$ & Inoculum & Yield & $\begin{array}{r}\text { Initial } \\
\mathrm{pH}\end{array}$ & $\begin{array}{r}\text { Optimum } \\
\mathrm{pH}\end{array}$ & $\begin{array}{l}\mathrm{pH} \\
\text { Management }\end{array}$ & $\begin{array}{r}\text { Temperature } \\
\left({ }^{\circ} \mathrm{C}\right)\end{array}$ & References \\
\hline Food waste & Sludge & $64.48 \mathrm{~mL} \mathrm{H}_{2} / \mathrm{VS}_{\mathrm{fed}}$ & 7 & $4.8-6.4$ & Not controlled & 37 & Lin et al. (2013b) \\
\hline Food waste & Sludge & $250 \mathrm{ml} \mathrm{H}_{2} / \mathrm{VS}_{\text {removed }}$ & 6.5 & $6.5-5.2$ & Not controlled & 26 & Tawfik et al. (2011) \\
\hline Food waste & $\begin{array}{l}\text { Kitchen } \\
\text { wastewater }\end{array}$ & $148 \pm 42 \mathrm{~mL} \mathrm{H}_{2} / \mathrm{COD}_{\text {removed }}$ & $5 \pm 03$ & $5 \pm 0.3$ & Manually Controlled & 40 & Tawfik and El-Qelish (2014) \\
\hline Food waste & Sludge & $70 \mathrm{~mL} \mathrm{H}_{2} / \mathrm{VS}$ & 5.5 & 5.5 & Manually Controlled & 55 & Shin et al. (2004) \\
\hline Rice waste & Sludge & $71 \mathrm{~mL} \mathrm{H}_{2} / \mathrm{VS}$ & 7 & 7 & Not controlled & 37 & Okamoto et al. (2000) \\
\hline Rice waste & Sludge & $134 \mathrm{~mL} \mathrm{H}_{2} / \mathrm{VS}$ & 5.5 & 5.5 & Manually Controlled & 37 & Dong et al. (2009) \\
\hline Food waste & Sludge & $55 \mathrm{~mL} \mathrm{H}_{2} / \mathrm{VS}$ & 7 & 6 & Not controlled & 55 & Nathao et al. (2013) \\
\hline Rice waste & Sludge & $346 \mathrm{~mL} \mathrm{H}_{2} \mathrm{~g}^{-1}$ carbohydrates & 4.5 & 4.5 & Manually Controlled & 37 & Fang et al. (2006) \\
\hline $\begin{array}{l}\text { Noodle Industry } \\
\text { wastewater }\end{array}$ & $\begin{array}{l}\text { Anaerobic } \\
\text { microflora }\end{array}$ & $1.47 \mathrm{~mol} \mathrm{H}_{2} \mathrm{~mol}^{-1}$ hexose & $4.5-8.5$ & 5.2 & Controlled & 35 & Mizuno (2000) \\
\hline Food waste & Sludge & $44.83 \mathrm{~mL} \mathrm{H}_{2} \mathrm{~g}^{-1} \mathrm{COD}$ & 8 & $8-4.5$ & Not Controlled & 55 & $\begin{array}{l}\text { Wongthanate and } \\
\text { Chinnacotpong (2015) }\end{array}$ \\
\hline OFMSW & Sludge & $205 \mathrm{ml} \mathrm{H}_{2} \mathrm{~g}^{-1} \mathrm{VS}$ added & 5.5 & 5.5 & Automatic $\mathrm{pH}$ controller & 55 & Chu et al. (2008) \\
\hline Food waste & Sludge & $82.47 \mathrm{~mL} \mathrm{~g}^{-1} \mathrm{VS}_{\text {removed }}$ & 7 & $7-4.4$ & Not Controlled & 55 & This study \\
\hline Noodle waste & Sludge & $131.38 \mathrm{~mL} \mathrm{~g}^{-1} \mathrm{COD}_{\text {removed }}$ & 7 & $7-4.4$ & Not Controlled & 55 & This study \\
\hline Rice waste & Sludge & $44.90 \mathrm{~mL} \mathrm{~g}^{-1}$ glucose $\mathrm{removed}_{\text {rem }}$ & 7 & $7-4.3$ & Not Controlled & 37 & This study \\
\hline
\end{tabular}

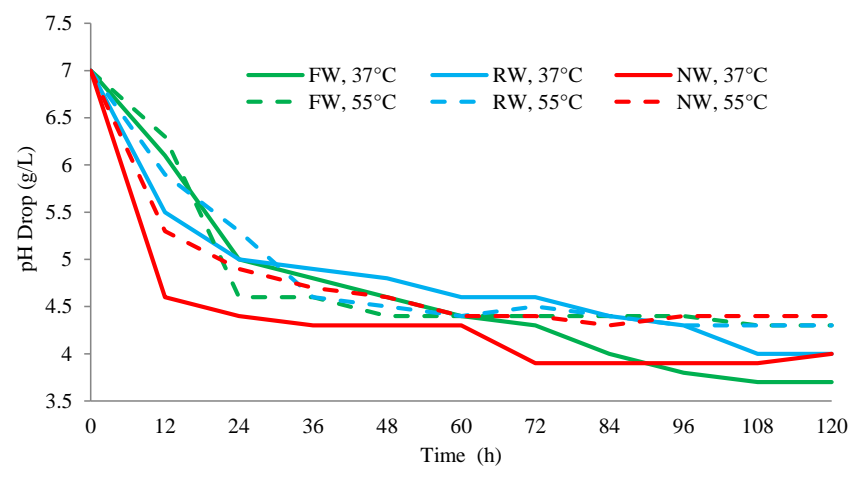

Figure 2. Effect of temperature on $\mathrm{pH}$ drop during incubation.

is much higher as compared to other values; this is because of the coefficient of determination that explained $98.58 \%$ variability. The quadratic model obtained from rice waste was not perfectly fit, but it can better explain results as compared to the model developed for all waste types as a whole.

The three-dimensional (3-D) response surfaces and twodimensional (2-D) contours were developed within the experimental range for each waste type by taking bio-hydrogen production as a response by using the above-mentioned equations. The 3-D and 2-D curves of the calculated response showed the interaction of incubation time and temperature in Fig. 3a-c. For food waste, it is clear that the gas production increases with time and temperature from $115 \mathrm{~mL}$ at the starting end to $354 \mathrm{~mL}$ at the extreme modelled conditions. Between 0 and $24 \mathrm{~h}$ of incubation, bio-hydrogen production increased with an increase in temperature for food waste, i.e. $115 \mathrm{~mL}$ of bio-hydrogen was produced at $37^{\circ} \mathrm{C}$ that increased to 76.09 and $152.17 \%$ at 46 and $55^{\circ} \mathrm{C}$, respectively. During the next $24 \mathrm{~h}$ of incubation, bio-hydrogen production reduced with the increase in temperature, i.e. $114.5 \mathrm{~mL}$ biohydrogen was produced at $37^{\circ} \mathrm{C}$ and 30.78 and $91.22 \%$ reduction was observed at $46^{\circ} \mathrm{C}$ and $55^{\circ} \mathrm{C}$, respectively. Even after reduction in bio-hydrogen production between 24 and $48 \mathrm{~h}$ of incubation, the cumulative bio-hydrogen production increased with an increase in temperature from food waste. The impact of temperature and time can be better viewed in 2-D contour (Fig. 3a), which shows that the increase in temperature increases bio-hydrogen production more at $24 \mathrm{~h}$ as compared to $72 \mathrm{~h}$ of incubation. It also revealed the fact that the first $24 \mathrm{~h}$ are important for bio-hydrogen production from food waste under thermophilic temperatures and the next 24 
are important for production under mesophilic temperature, which is in agreement with findings of Shin et al. (2004). Although noodle waste also produced more bio-hydrogen at elevated temperature, the time effect was opposite to that observed for food waste. The bio-hydrogen production in noodle waste during $0-24 \mathrm{~h}$ was $350 \mathrm{~mL}$ at $37^{\circ} \mathrm{C}$ that was 5.4 and $10.81 \%$ decreased at 46 and $55^{\circ} \mathrm{C}$, respectively. But in the next 24-72 h, there was an increase of 178.57 and $357.14 \%$ at 46 and $55^{\circ} \mathrm{C}$, respectively .

As far as rice waste was concerned, temperature has a negative impact on bio-hydrogen production. Between 24 to 48 $\mathrm{h}$, the bio-hydrogen production in rice waste was $131 \mathrm{~mL}$ at $37^{\circ} \mathrm{C}, 114.5 \mathrm{~mL}$ at $46^{\circ} \mathrm{C}$ and $98 \mathrm{~mL}$ at $55^{\circ} \mathrm{C}$. In next $24 \mathrm{~h}$, the bio-hydrogen production was reduced to $65.65 \%, 75.11 \%$ and $87.76 \%$ at $37^{\circ} \mathrm{C}, 46^{\circ} \mathrm{C}$ and $55^{\circ} \mathrm{C}$, respectively. The reduction in bio-hydrogen production for rice waste was in agreement with previous findings (Fang et al., 2006). The 2$\mathrm{D}$ contours in Fig. $3 \mathrm{~b}$ and $\mathrm{c}$ differentiate the impact of temperature with time on bio-hydrogen production for noodle waste and rice waste as the contour patterns are quite opposite to each other.

\subsection{Effect of temperature on bio-hydrogen yield}

The bio-hydrogen yield was calculated by dividing the $P$ value on Table 2 with $\mathrm{VS}_{\text {fed }}, \mathrm{VS}_{\text {removed }}$, COD removed and glucose $_{\text {removed }}$. The bio-hydrogen yield calculated on the basis of $\mathrm{VS}_{\text {fed }}$ lay in the range achieved by Lin et al. (2013b) and temperature impact on yield was the same as observed for $P$. The yield on the basis of $\mathrm{VS}_{\text {consumed }}$ represented uptake efficiency of VS during anaerobic digestion. The increase in $P$ with temperature for food waste was $23.41 \%$ whereas the yield increased by $2.86 \%$ only that indicated the efficient removal of VS at higher temperature. The biohydrogen yield calculated for FW on the basis of $\mathrm{VS}_{\text {removed }}$ lay in the range used by Kim et al. (2004). Using the same

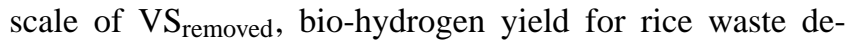
creased $47.37 \%$ with an increase in temperature, whereas the decrease in $P$ was $78.81 \%$ that represented a decrease in removal of VS at elevated temperature which was in agreement with the findings of Fang et al. (2006). As compared to food waste and noodle waste, the increase in $P$ and yield calculated by $\mathrm{VS}_{\text {removed }}$ was close, but it revealed the fact that VS removal efficiency slightly decreased at an elevated temperature.

When the yield measuring scale was shifted from $\mathrm{VS}_{\text {removed }}$ to $\mathrm{COD}_{\text {removed }}$, the results represented quite a different picture of temperature impact. The increase in temperature from 37 to $55^{\circ} \mathrm{C}$ increased $42.41 \%$ bio-hydrogen yield calculated on the basis of $\mathrm{COD}_{\text {removed }}$ for food waste. The increase in bio-hydrogen production due to same increase in temperature from 37 to $55^{\circ} \mathrm{C}$ was $23.37 \%$. Such a difference in yield and production increment represented a decrease in COD removal efficiency at an elevated temperature for food waste. For rice waste, the decrease in yield was $61 \%$, which
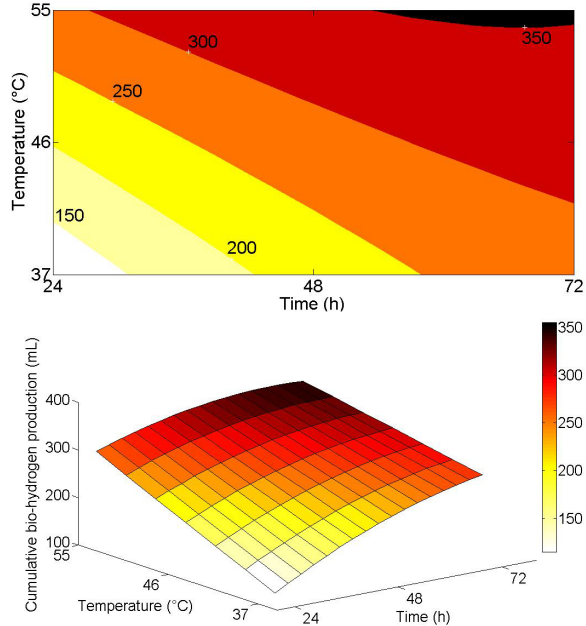

(a)
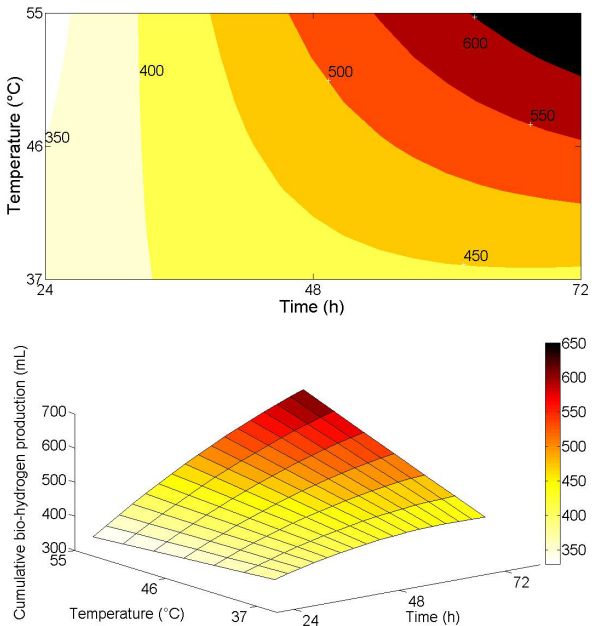

(b)
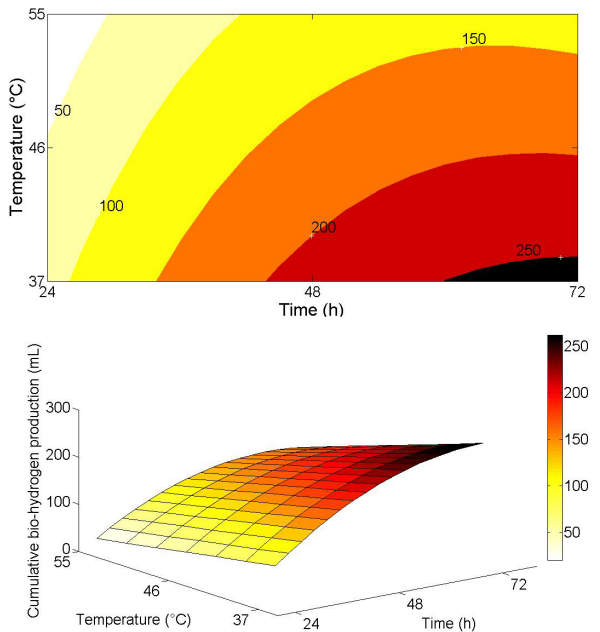

(c)

Figure 3. Three-dimensional response plots for bio-hydrogen production (a) Food waste, (b) Noodle waste, (c) Rice waste. 


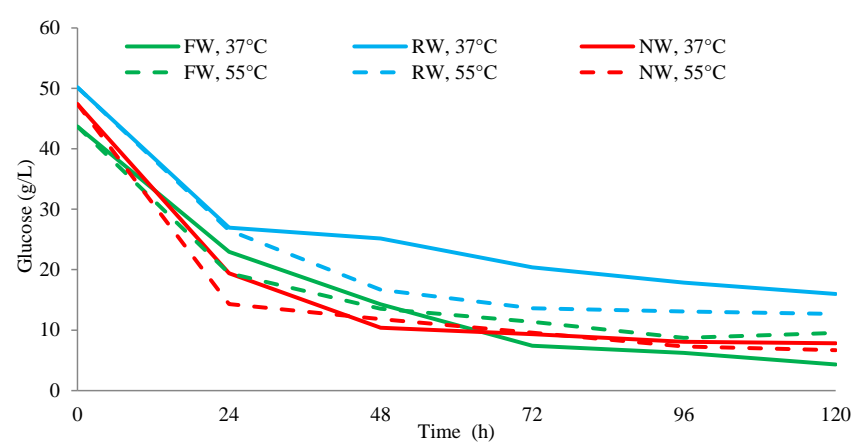

Figure 4. Glucose consumption during incubation under mesophilic and thermophilic temperature.

was close to a $78 \%$ decrease in $P$. Increasing temperature also increased the yield for noodle waste to $20 \%$, which was smaller than the increase in $P$, representing a higher rate of COD removal at elevated temperature. All the bio-hydrogen yields calculated on the basis of $\mathrm{COD}_{\text {removed }}$ lay in the range calculated by Tawfik and El-Qelish (2014).

Glucose removal efficiency for food waste decreased with an increase in temperature as the increase in $P$ was 23.41 against $42.19 \%$ when bio-hydrogen yield was calculated on

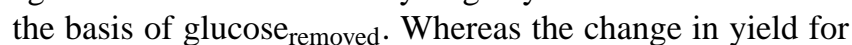
noodle waste and rice waste was close to the change observed for $P$. The decrease in glucose concentration was close to that observed in previous studies (Abdeshahian et al., 2014; Kapdan and Kargi, 2006). The yield calculated on a glucose basis was further studied on a daily basis and it was observed that the highest yield of $33 \mathrm{~mL}$ glucose removed $^{-1}$ for 0-24 h duration belonged to noodle waste under mesophilic condition. During the next $24 \mathrm{~h}$ period, the highest yield of $400 \mathrm{~mL}$ glucose $\mathrm{removed}_{\text {remo }}^{-1}$ was achieved by noodle waste under thermophilic temperature, which was close to the finding of Fang et al. (2006) but still smaller than the theoretical yield of $553 \mathrm{~mL} \mathrm{~g}^{-1}$ carbohydrate. The yield for rice waste also increased under both temperatures but it was much higher at mesophilic as $184.37 \mathrm{~mL}$ glucose $_{\text {removed }}^{-1}$ against $24.99 \mathrm{~mL}$ glucose $\mathrm{removed}^{-1}$ at thermophilic temperature. During 24 to $72 \mathrm{~h}$ of incubation, the yield in all reactors reduced except noodle waste under mesophilic conditions. As a whole, 24-48 h duration of incubation was found to be more important for bio-hydrogen production from glucose. The production of glucose modelled by quadratic equation using previ- ously defined notation as

$$
\begin{aligned}
& Y=13.504-0.604 x_{1}+0.095 x_{2}-0.831 x_{3}+0.066 x_{1}^{2} \\
& -5.469 x_{2}^{2}+0.609 x_{1} x_{2}+0.238 x_{1} x_{3}-1.131 x_{2} x_{3} \\
& \left(R^{2}=0.6959 F=64.07\right) .
\end{aligned}
$$

As the coefficient of determination is not so high so quadratic modelling was done for each waste type as

Food waste : $Y=7.820-3.561 x_{1}+0.412 x_{2}$

$$
+1.554 x_{1}^{2}+1.094 x_{1} x_{2}\left(R^{2}=0.9713 F=270.81\right)
$$

Noodle waste : $Y=8.697-1.601 x_{1}+0.055 x_{2}$

$+0.439 x_{1}^{2}-0.307 x_{1} x_{2}\left(R^{2}=0.7994 F=31.89\right)$

Rice Waste : $Y=21.817-3.1 x_{1}-0.938 x_{2}$

$$
-0.323 x_{1}^{2}-0.354 x_{1} x_{2}\left(R^{2}=0.715 F=20.07\right) \text {. }
$$

The 3-D response plots and contours for glucose removal were developed by the above models (Fig. 5). It was observed that in the first $24 \mathrm{~h}$ of incubation, the rate of utilization of glucose increased, with an increase in temperature up to $55^{\circ} \mathrm{C}$ for food waste, decreased for noodle waste, and remained almost unaffected for rice waste. The sequence for glucose utilization rate was in the rank of NW $>\mathrm{FW}>\mathrm{RW}$. Between 24 and $48 \mathrm{~h}$, glucose utilization rate decreased for food waste and increased for noodle and rice waste under mesophilic and thermophilic conditions. Between 48 and $72 \mathrm{~h}$, rate of utilization remained the same as previous one but rank was slightly changed as $\mathrm{FW}>\mathrm{RW}>\mathrm{NW}$. With an increase in temperature, between 24 and $72 \mathrm{~h}$, the rate of glucose utilization decreased for food waste but increased for noodle and rice waste. As a whole, the glucose consumption at the end of incubation was higher at $37^{\circ} \mathrm{C}$ as compared to $55^{\circ} \mathrm{C}$ for food waste. At the end of incubation, noodle waste and rice waste represented quite opposite picture of glucose consumption with temperature as observed for food waste. The contours represented a better understanding for glucose consumption and the contour varied in different manners for each waste type as shown in Fig. 5.

\subsection{Effect of temperature on VFA production}

The VFA revealed an increase with time as reported by Lin et al. (2013b), which is shown in Fig. 6. In the present study, it is observed that VFA in food waste and noodle waste increased with an increase in temperature from 37 to $55^{\circ} \mathrm{C}$ but decreased for rice waste that lay in the range calculated by Shin et al. (2004). It can be seen in Fig. 6 that between 24 and $48 \mathrm{~h}$, an increase in VFA was much higher in food waste under thermophilic conditions as compared to mesophilic conditions. During the same interval, bio-hydrogen production almost ceased in the thermophilic food waste reactor whereas it was continuously producing in mesophilic food waste reactor. One of the possible reasons for this reduction is the conversion of glucose to VFA at 

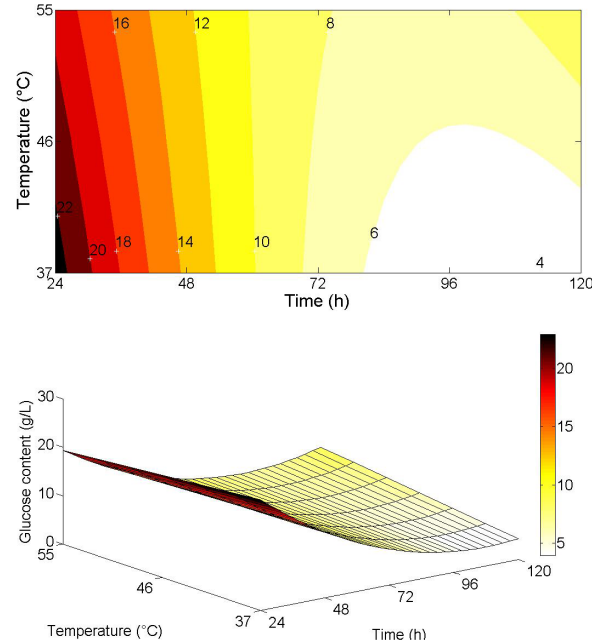

(a)
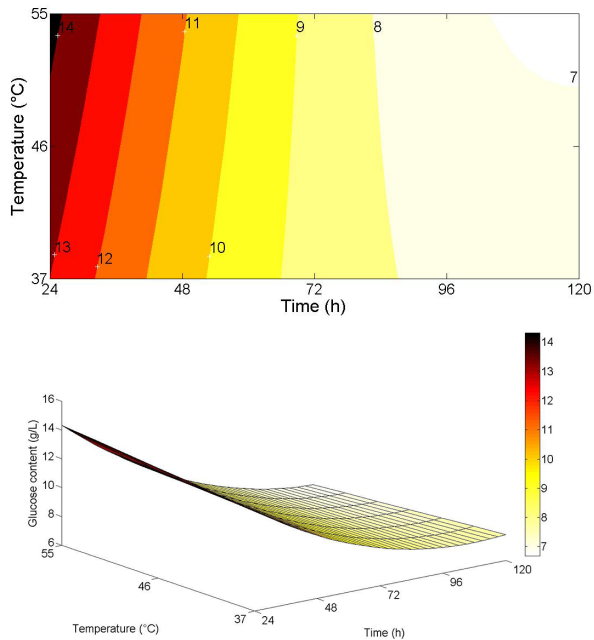

(b)
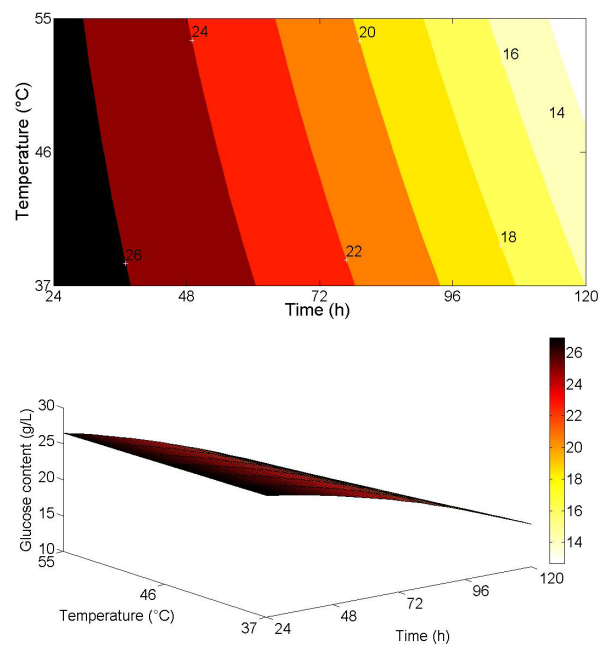

(c)

Figure 5. Three-dimensional response plots for glucose consumption (a) Food waste, (b) Noodle waste, (c) Rice waste.

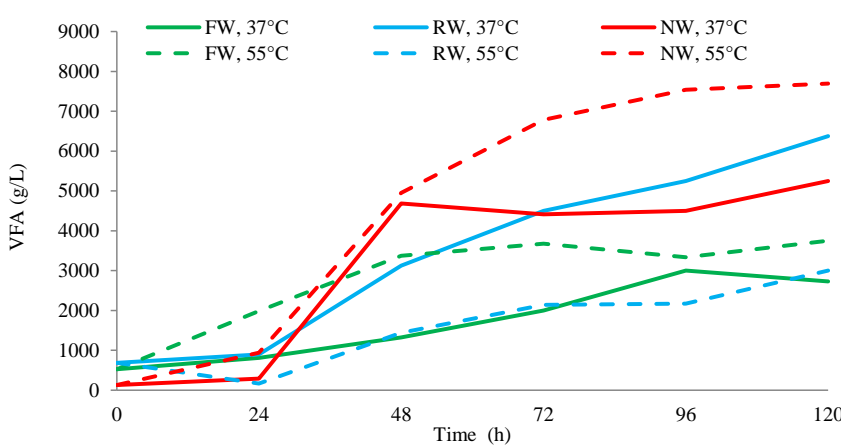

Figure 6. Increase in VFA concentration with time under mesophilic and thermophilic temperatures.

this stage by homoacetogenic bacteria that reached up to such a level where bio-hydrogen production was not feasible under thermophilic conditions, whereas the VFA production in the mesophilic FW reactor was much smaller than that observed under thermophilic reactor, because of which production continued in the mesophilic reactor (Zhang et al., 2014). The higher concentration of VFA together with low $\mathrm{pH}$ can be inhibitory to bacteria that can cause unfavourable physical changes in the cell. By such physical changes, excessive energy is required to pump ions and that energy can be available at a higher temperature. So it increased the yield at elevated temperatures, as observed in the case of food waste and noodle waste (Gottschalk, 1986; Zoetemeyer, 1982; Switzenbaum, 1990). The higher concentration of VFA can also be used as an indicator for higher production of bio-hydrogen as observed by Dong et al. (2009). In the present study, the order to VFA production and cumulative bio-hydrogen production was the same i.e. $\mathrm{NW}_{55^{\circ} \mathrm{C}}>\mathrm{RW}_{37{ }^{\circ} \mathrm{C}}>\mathrm{NW}_{37^{\circ} \mathrm{C}}>\mathrm{FW}_{55^{\circ} \mathrm{C}}>\mathrm{FW}_{37{ }^{\circ} \mathrm{C}}>\mathrm{RW}_{37{ }^{\circ} \mathrm{C}}$.

The quadratic model was tried to fit for VFA production data in the same way as opted for glucose and the resultant equation was as follows:

$$
\begin{aligned}
& Y=1795.82+686.16 x_{1}-300.51 x_{2}+641.13 x_{3} \\
& +4.94 x_{1}^{2}+658.51 x_{2}^{2}+127.30 x_{1} x_{2}+33.26 x_{1} x_{3} \\
& -319.25 x_{2} x_{3}\left(R^{2}=0.5975 F=41.56\right) .
\end{aligned}
$$

Here, again the coefficient of determination is not so high due to the variability of waste type, so the model was repeated for each waste as 
Food waste : $Y=2362.67+458.15 x_{1}+545.05 x_{2}$

$-12.88 x_{1}^{2}+2.76 x_{2}^{2}-22.42 x_{1} x_{2}$

$\left(R^{2}=0.8654 F=51.44\right)$

Noodle waste : $Y=4196.48+1464.56 x_{1}$

$+772.876 x_{2}-163.19 x_{1}^{2}+224.98 x_{1} x_{2}$

$\left(R^{2}=0.8415 F=42.48\right)$

Rice waste : $Y=3258.94+756.62 x_{1}-1147.22 x_{2}$

$-303.1 x_{1}^{2}-390.28 x_{1} x_{2}$

$\left(R^{2}=0.9430 F=132.37\right)$.

The 3-D response plots and contours for VFA production on the basis of the above models are shown in Fig. 7. The 3D contours for food waste and noodle waste seem almost same but the contour lines for both varied in a different manner. Although the production of VFA increased with time and temperature in all reactors but the intensity of change is different for each waste type as observed in Fig. 7. It can be observed from Fig. 7 that the production of VFA has increased for food waste and noodle waste when temperature was increased from 37 to $55^{\circ} \mathrm{C}$. Although with time, the VFA concentration increased, but the rate by which VFAs produced was decreased with time, i.e. VFA production between 24 and $48 \mathrm{~h}$ was greater than that produced between 48 and $72 \mathrm{~h}$ and this trend continued until $120 \mathrm{~h}$ for food waste and noodle waste. As a whole, more VFA was produced between 24 and $120 \mathrm{~h}$ under mesophilic temperature as compared to thermophilic temperature in food waste reactor, but as a whole, mesophilic VFA production was found to be less than that of thermophilic as reported by Gadow et al. (2012). It is because of the fact that between 0 and $24 \mathrm{~h} \mathrm{du}$ ration, thermophilic VFA production was much higher than that produced under mesophilic conditions in food waste. By controlling the VFA production during this interval, the yield of bio-hydrogen can be increased for FW as it stopped too early in thermophilic food waste reactor as compared to mesophilic food waste reactor. Thermophilic VFA production was higher than mesophilic VFA production in noodle waste reactor. On the other end, mesophilic VFA production was higher than that produced under thermophilic conditions for RW and VFA increased with time in the same manner as observed for food waste under $40^{\circ} \mathrm{C}$. Between 40 and $55,{ }^{\circ} \mathrm{C}$, the VFA trend for rice waste remained the same as of food waste until $96 \mathrm{~h}$ after which it started to decrease until $120 \mathrm{~h}$.

\section{Conclusion}

Food waste and its two major derivatives, i.e. noodle waste and rice waste, were co-digested with sewerage sludge to produce bio-hydrogen with an initial $\mathrm{pH}$ of 7 under mesophilic and thermophilic conditions. The $\mathrm{pH}$ was not
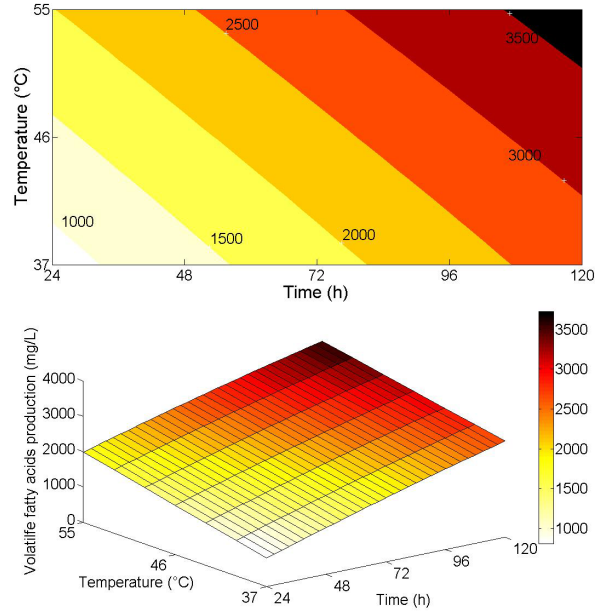

(a)
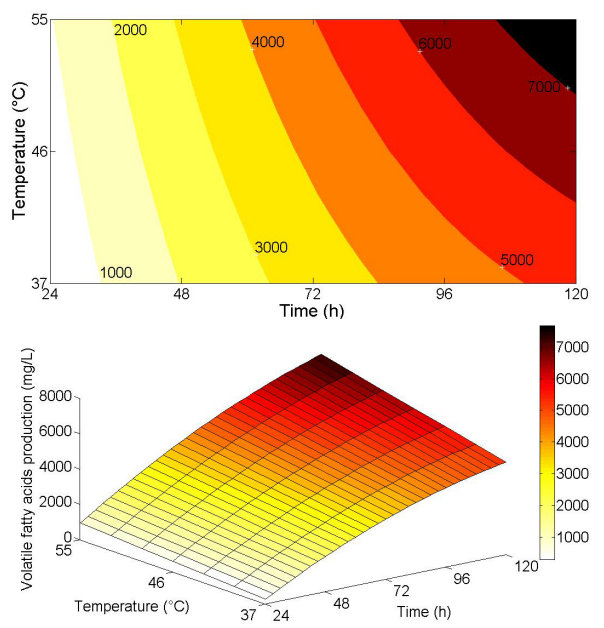

(b)
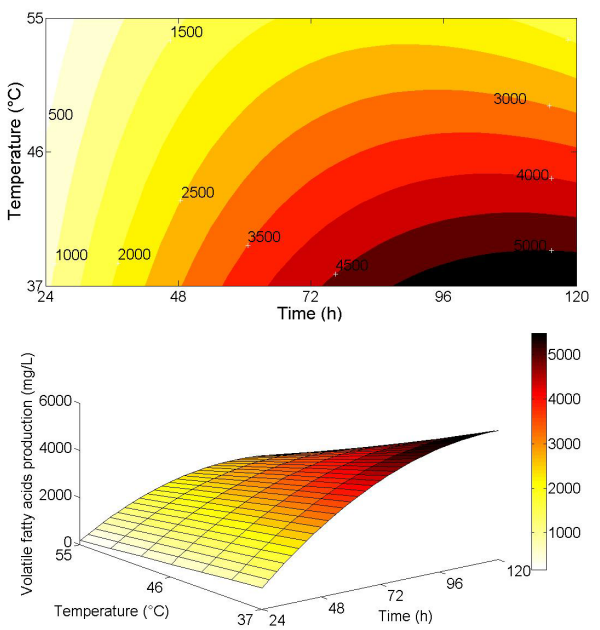

(c)

Figure 7. Three-dimensional response plots for VFA production (a) Food waste, (b) Noodle waste, (c) Rice waste. 
controlled throughout the incubation. The most effective VS removal was observed in noodle waste reactor that produced the highest experimental cumulative bio-hydrogen of $656.5 \mathrm{~mL}$ under thermophilic conditions. The food waste possessed the highest bio-hydrogen yield calculated on the basis of $\mathrm{VS}_{\text {removed }}$ that represents an efficient conversion of VS into bio-hydrogen. The increase in temperature within the studied range increased the bio-hydrogen production in food waste and noodle waste reactors. The rice waste reactor represented the negative impact of increasing temperature on bio-hydrogen and VFA production. Thermophilic conditions should be preferred for bio-hydrogen production as most of the time food waste is used as feed stock. The quadratic modelling returned good results that were close to experimental ones, when it was done for each waste type of bio-hydrogen, VFA production and glucose removal. The response surface plots and contour plots within the experimental range adequately explained the effect of temperature and time on studying parameters and helped to develop better understanding regarding the variation among the studied parameters especially when the different treatments represented similar trends. VFA production in rice waste reactor changes the trend after $40^{\circ} \mathrm{C}$ that was identified only due to quadratic modelling. The lowest limit of $\mathrm{pH}$ for bio-hydrogen production was identified as 4.3 and 4.4 for mesophilic and thermophilic temperatures respectively.

Author contributions. C. Arslan and A. Sattar, designed the research and performed all the lab works. C. Ji provided the financial and technical support for designing and conducting research as well as supervised the whole research process. S. Sattar developed and customized 3-D surface plots and assisted in manuscript preparation. K. Yousaf assisted the lab works and analysis. S. Hashim performed the statistical analysis. C. Arslan wrote the manuscript with comments from all authors and A. Sattar finalized the manuscript under the supervision and guidelines of C. Ji.

Acknowledgements. We thank K. Chen for providing lab facilities; H. Fang, Y. P. Huang and J. B. Kang for their help during lab work; I. A. Mari for field work and technical assistance; F. A. Chandio and F. Ahmad for helpful discussion and critical review. We extend our thank to Higher Education Commission, Pakistan, China Scholarship council and the College of Engineering, Nanjing Agricultural University, Nanjing for supporting and providing research facilities for this study.

Edited by: T. Treude

\section{References}

Abdeshahian, P., Al-Shorgani, N. K. N., Salih, N. K., Shukor, H., Kadier, A., Hamid, A. A., and Kalil, M. S.: The production of biohydrogen by a novel strain Clostridium sp. YM1 in dark fermentation process, Int. J. Hydrogen Energ., 39, 12524-12531, 2014.

APHA: Standard Methods for the Examination of Water and Wastewater., 25 Edn., American Public Health Association, Washington, D.C., 94-100, 2005.

Chen, W.-H., Chen, S.-Y., Kumar Khanal, S., and Sung, S.: Kinetic study of biological hydrogen production by anaerobic fermentation, Int. J. Hydrogen Energ., 31, 2170-2178, 2006.

Chu, C.-F., Li, Y.-Y., Xu, K.-Q., Ebie, Y., Inamori, Y., and Kong, H.$\mathrm{N}$.: A pH-and temperature-phased two-stage process for hydrogen and methane production from food waste, Int. J. Hydrogen Energ., 33, 4739-4746, 2008.

Dong, L., Zhenhong, Y., Yongming, S., Xiaoying, K., and Yu, Z.: Hydrogen production characteristics of the organic fraction of municipal solid wastes by anaerobic mixed culture fermentation, Int. J. Hydrogen Energ., 34, 812-820, 2009.

Duangmanee, T., Padmasiri, S., Simmons, J., Raskin, L., and Sung, S.: Hydrogen production by anaerobic microbial communities exposed to repeated heat treatments, Water Environ. Res., 79, 975-983, 2007.

Fang, H. H., Li, C., and Zhang, T.: Acidophilic biohydrogen production from rice slurry, Int. J. Hydrogen Energ., 31, 683-692, 2006.

Gadow, S., Li, Y.-Y., and Liu, Y.: Effect of temperature on continuous hydrogen production of cellulose, Int. J. Hydrogen Energ., 37, 15465-15472, 2012.

Gottschalk, G.: Bacterial metabolism, 2nd Edn., Springer, New York, 1986.

Han, H. K. and Shin, S. H.: Performance of an innovative two-stage process converting food waste to hydrogen and methane, J. Air Waste Manage., 54, 242-249, 2004.

Heidrich, E., Dolfing, J., Scott, K., Edwards, S., Jones, C., and Curtis, T.: Production of hydrogen from domestic wastewater in a pilot-scale microbial electrolysis cell, Appl. Microbiol. Biot., 97, 6979-6989, 2013.

Hu, C. C., Giannis, A., Chen, C.-L., and Wang, J.-Y.: Evaluation of hydrogen producing cultures using pretreated food waste, Int. J. Hydrogen Energ., 39, 19337-19342, 2014.

Jo, J. H., Lee, D. S., Park, D., Choe, W.-S., and Park, J. M.: Optimization of key process variables for enhanced hydrogen production by Enterobacter aerogenes using statistical methods, Bioresource Technol., 99, 2061-2066, 2008.

Kapdan, I. K. and Kargi, F.: Bio-hydrogen production from waste materials, Enzyme Microb. Tech., 38, 569-582, 2006.

Kim, S.-H., Han, S.-K., and Shin, H.-S.: Feasibility of biohydrogen production by anaerobic co-digestion of food waste and sewage sludge, Int. J. Hydrogen Energ., 29, 1607-1616, 2004.

Kim, S.-H., Han, S.-K., and Shin, H.-S.: Optimization of continuous hydrogen fermentation of food waste as a function of solids retention time independent of hydraulic retention time, Process Biochem., 43, 213-218, 2008.

Lay, J.-J. and Fan, K.-S.: Influence of chemical nature of organic wastes on their conversion to hydrogen by heat-shock digested sludge, Int. J. Hydrogen Energ., 28, 1361-1367, 2003.

Li, C. and Fang, H. H.: Fermentative hydrogen production from wastewater and solid wastes by mixed cultures, Crit. Rev. Env. Sci. Tec., 37, 1-39, 2007. 
Li, Q. and Liu, C.-Z.: Co-culture of Clostridium thermocellum and Clostridium thermosaccharolyticum for enhancing hydrogen production via thermophilic fermentation of cornstalk waste, Int. J. Hydrogen Energ., 37, 10648-10654, 2012.

Lin, Y., Wang, D., Li, Q., and Xiao, M.: Mesophilic batch anaerobic co-digestion of pulp and paper sludge and monosodium glutamate waste liquor for methane production in a bench-scale digester, Bioresource Technol., 102, 3673-3678, 2011.

Lin, Y., Liang, J., Wu, S., and Wang, B.: Was pretreatment beneficial for more biogas in any process? Chemical pretreatment effect on hydrogen-methane co-production in a two-stage process, J. Ind. Eng. Chem., 19, 316-321, $2013 \mathrm{a}$.

Lin, Y., Wu, S., and Wang, D.: Hydrogen-methane production from pulp \& paper sludge and food waste by mesophilic-thermophilic anaerobic co-digestion, Int. J. Hydrogen Energ., 38, 1505515062, 2013b.

Lu, L., Ren, N., Zhao, X., Wang, H., Wu, D., and Xing, D.: Hydrogen production, methanogen inhibition and microbial community structures in psychrophilic single-chamber microbial electrolysis cells, Energ. Environ. Sci., 4, 1329-1336, 2011.

Luo, G., Xie, L., Zou, Z., Wang, W., Zhou, Q., and Shim, H.: Anaerobic treatment of cassava stillage for hydrogen and methane production in continuously stirred tank reactor (CSTR) under high organic loading rate (OLR), Int. J. Hydrogen Energ., 35, 1173311737, 2010.

McCarty, P. L.: One hundred years of anaerobic treatment, Anaerobic Digestion, 3-22, 1981.

Mizuno, O., Shinya, M., Suzuki, K., Yaguchi, J., and Noike, T. E: Effect of $\mathrm{pH}$ on Hydrogen Production from Noodle Manufacturing Wastewater, Environ. Eng. Res., 37, 97-106, 2000 (in Japanese).

Nathao, C., Sirisukpoka, U., and Pisutpaisal, N.: Production of hydrogen and methane by one and two stage fermentation of food waste, Int. J. Hydrogen Energ., 38, 15764-15769, 2013.

Nielsen, A. T., Amandusson, H., Bjorklund, R., Dannetun, H., Ejlertsson, J., and Ekedahl, L. G.: Hydrogen production from organic waste, Int. J. Hydrogen Energ., 26, 547-550, 2001.

Okamoto, M., Miyahara, T., Mizuno, O., and Noike, T.: Biological hydrogen potential of materials characteristic of the organic fraction of municipal solid wastes, Water Sci. Technol., 41, 25-32, 2000.

Payot, R., Guedon, E., Cailliez, C., Gelhage, E., and Petitdemange, H.: Metabolism of cellobiose by Clostridium cellulolyticum growing in continuous culture: evidence for decreased NADH reoxidation as a factor limiting growth, Microbiology, 144, 375384, 1998

Radjaram, B. and Saravanane, R.: Assessment of optimum dilution ratio for biohydrogen production by anaerobic co-digestion of press mud with sewage and water, Bioresource Technol., 102, 2773-2780, 2011.

Ramos, C., Buitrón, G., Moreno-Andrade, I., and Chamy, R.: Effect of the initial total solids concentration and initial $\mathrm{pH}$ on the biohydrogen production from cafeteria food waste, Int. J. Hydrogen Energ., 37, 13288-13295, 2012.

Reungsang, A., Sreela-or, C., and Plangklang, P.: Non-sterile biohydrogen fermentation from food waste in a continuous stirred tank reactor (CSTR): Performance and population analysis, Int. J. Hydrogen Energ., 38, 15630-15637, 2013.
Sahlström, L.: A review of survival of pathogenic bacteria in organic waste used in biogas plants, Bioresource Technol., 87, 161-166, 2003.

Saraphirom, P. and Reungsang, A.: Optimization of biohydrogen production from sweet sorghum syrup using statistical methods, Int. J. Hydrogen Energ., 35, 13435-13444, 2010.

Saripan, A. F. and Reungsang, A.: Simultaneous saccharification and fermentation of cellulose for bio-hydrogen production by anaerobic mixed cultures in elephant dung, Int. J. Hydrogen Energ., 39, 9028-9035, 2014.

Schiel-Bengelsdorf, B. and Dürre, P.: Pathway engineering and synthetic biology using acetogens, FEBS Lett., 586, 2191-2198, 2012.

Shin, H.-S., Youn, J.-H., and Kim, S.-H.: Hydrogen production from food waste in anaerobic mesophilic and thermophilic acidogenesis, Int. J. Hydrogen Energ., 29, 1355-1363, 2004.

Shiwei, X.: Analysis of China food consumption and waste, food and nutrition in China, China Food and Nutrition, 11, 4-8, 2005.

Switzenbaum, M. S., Giraldo-Gomez, E., and Hickey, R. F.: Monitoring of the anaerobic methane fermentation process. Enzyme Microbial Technology, Enzyme Microb. Techn., 12, 722-730, 1990.

Tai, J., Zhang, W., Che, Y., and Feng, D.: Municipal solid waste source-separated collection in China: A comparative analysis, Waste Manage., 31, 1673-1682, 2011.

Tawfik, A., Salem, A., and El-Qelish, M.: Two stage anaerobic baffled reactors for bio-hydrogen production from municipal food waste, Bioresource Technol., 102, 8723-8726, 2011.

Tawfik, A. and El-Qelish, M.: Key factors affecting on bio-hydrogen production from co-digestion of organic fraction of municipal solid waste and kitchen wastewater, Bioresource Technol., 168, 106-111, 2014.

Wang, L., Cheng, S., Li, Q., and Zengrang, X.: Tourist Dining Behavior in Lhasa City, Resources Science, 35, 848-857, 2013 (in Chinese).

Wang, Y.-Y., Ai, P., Hu, C.-X., and Zhang, Y.-L.: Effects of various pretreatment methods of anaerobic mixed microflora on biohydrogen production and the fermentation pathway of glucose, Int. J. Hydrogen Energ., 36, 390-396, 2011.

Wongthanate, J. and Chinnacotpong, K.: Optimal Conditons for Biological Hydrogen Production from Food Waste, Environ. Eng. Res., 20, 121-125, 2015.

Yasin, N. H. M., Man, H. C., Yusoff, M. Z. M., and Hassan, M. A.: Microbial characterization of hydrogen-producing bacteria in fermented food waste at different $\mathrm{pH}$ values, Int. J. Hydrogen Energ., 36, 9571-9580, 2011.

Yokoyama, H., Waki, M., Moriya, N., Yasuda, T., Tanaka, Y., and Haga, K.: Effect of fermentation temperature on hydrogen production from cow waste slurry by using anaerobic microflora within the slurry, Appl. Microbiol. Biot., 74, 474-483, 2007.

Zhang, L., Ban, Q., Li, J., and Xu, Y.: Assessment of Effects of Yeast Extract on Bio-hydrogen Production from Anaerobic Activated Sludge, Int. J. Agric. Biol, 16, 1189-1193, 2014.

Zhang, R., El-Mashad, H. M., Hartman, K., Wang, F., Liu, G., Choate, C., and Gamble, P.: Characterization of food waste as feedstock for anaerobic digestion, Bioresource Technol., 98, 929-935, 2007. 
Zhu, H., Parker, W., Basnar, R., Proracki, A., Falletta, P., Béland, M., and Seto, P.: Biohydrogen production by anaerobic codigestion of municipal food waste and sewage sludges, Int. J. Hydrogen Energ., 33, 3651-3659, 2008.
Zoetemeyer, R. J. M. A., Cohen, A., and Boelhouwer, C.: Product inhibition in the acid forming stage of the anaerobic digestion process, Water Res., 16, 633-639, 1982. 